\title{
Doped calcium carbonate-phosphate used for bone tissue technology
}

\author{
Lyubov Fedorovna Koroleva ${ }^{1 *}$, Maria Nikolaevna Dobrinskaya ${ }^{2}$ and Ivan Sergeevich Kamantsev ${ }^{1}$ \\ ${ }^{1}$ Institute of Engineering Science, Ural Branch of the Russian Academy of Sciences, 34 Komsomolskaya st., Ekaterinburg, Russian Federation \\ ${ }^{2}$ Ural State Medical University, 3 Repina st., Ekaterinburg, Russian Federation
}

\begin{abstract}
Doped with $\mathrm{K}^{+}, \mathrm{Mg}^{2+}, \mathrm{Fe}^{2+}, \mathrm{Zn}^{2+}, \mathrm{Mn}^{2+}, \mathrm{Li}^{+}, \mathrm{Au}^{3+}, \mathrm{SiO}_{2}$ nanocrystalline calcium carbonate-phosphate extends significantly the functionality for drug delivery: it can be used to speed up the processes of bone repair and bone tissue strengthening. The advantage over other calcium phosphate biomaterials is strengthening of bone and tooth tissues of a human being of any age, the substances being transported through skin to restore broken bones in a critically short period of time regardless of age. The mechanical fracture strength of bone tissue increases almost in 5 times. These studies suggest doped calcium carbonate-phosphate is the most appropriate material, because reduce of the cholesterol rate in the blood in 2-2.5 time. The best results have been observed with concentrations of 5-10\% doped calcium carbonatephosphate in the implant used the polycaprolactone. Young`s modulus is maximal for specimens with 5\% doped calcium carbonate-phosphate.
\end{abstract}

\section{Introduction}

Tissue engineering is intensively researching solutions that have the potential to reduce the complications related to current treatment methods. Tissue engineering can be defined as an interdisciplinary field that applies the principles of engineering and life sciences to develop biological substitutes that restore, maintain or improve tissue function. This concept involves three main strategies: the use of isolated cells or cell substitutes to replace limited functions of the tissue; utilization of tissue-inducing substances such as growth factors; and scaffolds to direct tissue development. Calcium phosphate has been the subject of many studies in the last decade because of it biocompatibility, ability to fill bone cavities and properties which are desirable for surgical applications. The synthesis of nanocrystalline calcium hydroxyapatites for the fabrication of composite materials as bone graft substitutes is a critical issue in bioceramic research [1-11].

There is considerable interest in the study of the interaction of the surface of hydroxyapatite crystals and their coatings with amine- and carboxy-groups of proteins in relation to the resorption of biomaterials and osteogenesis in living organisms [12]. Such processes of bone regeneration were takes from four to six months $[13,14]$. Hydroxyapatite is known to be very similar in composition to the inorganic component of bone tissue: the dry residue of bone tissue consists of $70 \%$ hydroxyapatite and $30 \%$ organic component of collagen. In addition to $\mathrm{Ca}^{2+}$ and $\mathrm{PO}_{4}^{3-}$, calcium hydroxyapatite in bone tissue contains $\mathrm{Na}^{+}, \mathrm{K}^{+}, \mathrm{Mg}^{2+}, \mathrm{Fe}^{2+}, \mathrm{Si}^{4+}, \mathrm{Cl}^{-}$и $\mathrm{CO}_{3}^{2-}$ possibly $\mathrm{Zn}^{2+}$, and the less desirable ions $\mathrm{Sr}^{2+}, \mathrm{Al}^{3+}, \mathrm{Pb}^{2}$ [15-18].

It is necessary to create a material based on inorganic calcium phosphates, which are easily assimilated, and not only through the gastrointestinal tract. Doped nanocrystalline calcium carbonatephosphate is a biocompatible material that has an active effect on osteogenesis, including activity through the skin, on the strengthening of bone and dental tissues [19-22].

The morphology, stability, degree of crystalline and mechanical properties of calcium hydroxyapatite depend on isomorphous substitution of calcium on such cations as $\mathrm{Na}^{+}, \mathrm{K}^{+}, \mathrm{Mg}^{2+}, \mathrm{Fe}^{2+}, \mathrm{Zn}^{2+}$. They play an important role in the biological process of the osteogenesis [23-26].

It is also known elements such as platinum, gold in the colloid form previously used as a treatment for rheumatoid arthritis in humans and tumors, but used doses were accompanied with side effect [27-29]. In case of a possible transfer of cations $\mathrm{Au}$ and $\mathrm{Pt}$ on molecules doped nanocrystalline carbonate-calcium phosphates dose can be significantly reduced, that would nullify the adverse effects to a minimum, at the same time, will reach the therapeutic effect. In the synthesis of alloyed gold and platinum carbonate-calcium phosphates concentrations of these elements make up the thousandths parts mole.

The bioactivity of calcium phosphates can be enhanced by partial substitution of carbonate groups for phosphate groups, leading to the formation of calcium deficient hydroxyapatites, containing cation vacancies, which ensures the incorporation of doping microelements into the crystal structure of the material. The processes for the preparation of calcium hydroxyapatite are well documented in the literature. They can be divided into high temperature (pyrolysis) and low temperature (precipitation and hydrolysis) processes.

Previously the mechanism of the synthesis of nanocrystalline doped calcium carbonate-phosphate was considered and proposed a model to describe the kinetics of oscillating system as brusselator of simple cubic nonlinearity. The mechanism of obtaining this biomaterial is quite

Correspondence to: Lyubov Fedorovna Koroleva, 34, Komsomolskaya st. 620049, Ekaterinburg, Russian Federation, Tel: +7 343 3741853; Fax: +7 343 3745330; E-mail: lq@imach.uran.ru

Key words: biocompatible materials doped, calcium carbonate-phosphate, implant, transdermal, mechanical properties, osteogenesis, bone and dental tissues

Received: May 03, 2017; Accepted: May 27, 2017; Published: June 01, 2017 
difficult, and this process can be considered as oscillating reactions in living organism [30].

The simplest classic example of the existence of autooscillations in the system of chemical reactions is the trimolecular model ("brusselator") offered by I.R. Prigozhine and R. Lefever [31]. The main purpose for the study of this model was to determine the qualitative types of behavior, which are compatible with the fundamental laws of chemical and biological kinetics. In this context, the brusselator plays the role of a basic model, like a harmonic oscillator in physics. A classic brusselator model describes the hypothetical scheme of chemical reactions: $\mathrm{A} \rightarrow \mathrm{X} ; \mathrm{B}+\mathrm{X} \rightarrow \mathrm{Y}+\mathrm{C} ; 2 \mathrm{X}+\mathrm{Y} \rightarrow 3 \mathrm{X} ; \mathrm{X} \rightarrow \mathrm{R} ; \mathrm{A}+\mathrm{B} \rightarrow \mathrm{R}+\mathrm{C}$. The key is the stage of transformation of two $X$ molecules and one $Y$ molecule into $X$ (the so-called trimolecular reaction). The nonlinearity of this reaction, coupled with processes of diffusion of the substance, guarantees the possibility of space-time regimes as well as the formation spatial structures in an initially homogeneous system of morphogenesis. Although the trimolecular reaction occurs in chemical kinetics is not as common as bimolecular processes, expressions for the speed of some chemical reactions in some definite cases can be called cubic-type.

The properties of time dependent wave function are determined by the views of potential energy surface and initial state $\Psi(\mathrm{x}, 0)$. The physical significance of wave function is according to the Copenhagen interpretation of quantum mechanics, the probability density of finding a particle at a given point of space at this point in time is deemed to be equal to the square of the absolute value of the wave function of this condition in the coordinate representation $[32,33]$.

A wide variety of chemical transformations can occur in areas where the potential surfaces of different electron states intersect. These areas in quantum dynamics called conical intersections. Reaching conical intersections, a wave packet is split: one part continues to move in the same State, and the second goes to a different State, which could in the future lead to different processes: dissociation, isomerization or radiation less transitions, in which the excitation energy is dissipated to other degrees of freedom. Splitting of wave packet was modeled by parallel reactions. The rate constants are determined of the electronic transition probability $\mathrm{p}[34]$ :

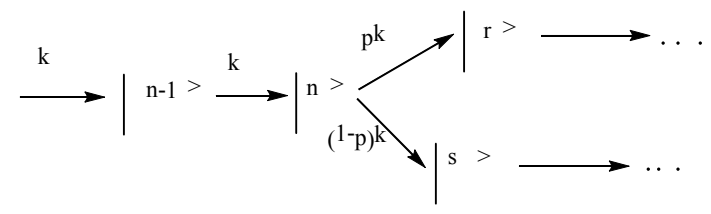

The probability of electronic transition in the field of conical intersection depends on the type of potential surfaces and the wave packet speed. Knowing the dependence of wave packet from time, $\Psi$ $(x, t)$, you can determine the probability of the individual channels of the chemical reaction, that is the output of products, as well as time of reaction. For the first time kinetic model was built for the reactions of straight dissociation of small molecules. These reactions are ones of the most simple (and therefore, most studied), since the dynamics bring to rupture of the one chemical bond [34].

The infinite movement of wave packet on this surface is described by a set of consecutive first- order reactions that you can observe in case of synthesis of doped calcium carbonate phosphates. Space time regimes, predicted in oscillating reaction-diffusion type models, can be observed in chemical reactions. Biochemical oscillations have been studied from complementary experimental and theoretical perspectives for many years. Well known instances are circadian rhythms and the oscillation of ATP and ADP concentrations during phosphorylation of fructose-6-phosphate in glycolysis [35,36].

Reaction of the synthesis of doped calcium carbonate- phosphate, which were described in [19-21], include several initial compounds as a calcium carbonate of three polymorphic crystal forms (calcite, aragonite, and vaterite), ortho-phosphoric acid, ammonium chloride, ammonium hydroxide, and microelements of the living organism $\left(\mathrm{K}^{+}\right.$, $\left.\mathrm{Mg}^{2+}, \mathrm{Fe}^{2+}, \mathrm{Zn}^{2+}, \mathrm{Mn}^{2+}, \mathrm{Li}^{+}, \mathrm{Au}^{3+}, \mathrm{SiO}_{2}\right)$.

This work deals with the effect of nanocrystalline calcium carbonatephosphate doped with cations of iron, magnesium, potassium, zinc, lithium, manganese, copper, gold, silicon, which is intended for bone repair by drug delivery; it is also studies the strengthening of bone tissue and the strength of ceramics to be used for implants.

\section{Materials and methods}

Calcium carbonate -phosphate samples doped by microelements were prepared using three $\mathrm{CaCO}_{3}$ polymorphous phases: calcite (rhombohedra structure), vaterite (hexagonal), and aragonite (orthorhombic). The last two phases are known to be metastable.

Calcium carbonate phosphates were precipitated by orthophosphoric acid, which was added to a calcium carbonate suspension in a solution of ammonium bicarbonate and ammonium chloride $(2 \mathrm{M})$ at $45-55^{\circ} \mathrm{C}$. The $\mathrm{pH}$ of the solution was 5.2 to 6.5 , depending on the $\mathrm{Ca} / \mathrm{P}$ molar ratio (1.55-1.67). Doping cations were added during calcium carbonate precipitation: $\mathrm{Fe}^{2+}$ and $\mathrm{Mg}^{2+}, 0.01-$ $0.06 ; \mathrm{Zn}^{2+}, 0.00015-0.002 ; \mathrm{K}^{+}, 0.05-0.3 ; \mathrm{SiO}_{2}, 0.0002-0.006$; and $\mathrm{Mn}^{2+}$, $\mathrm{Au}^{3+}-2 \times 10^{-5}$ to $1 \times 10^{-4} \mathrm{~mol} \%$.

The samples thus obtained were characterized by X-ray diffraction (XRD) (CuKa radiation; STADI-P diffractometer, software for diffraction peak identification using JCPDS-ICDD PDF2 data), IR spectroscopy (Shimadzu JR-475 spectrophotometer, $\mathrm{KBr}$ disk method). Particle-size analysis was performed with the Shimadzu SACP2 centrifugal analyzer (viscosity of the dispersion medium, 0.0093 $\mathrm{P}$; density of the liquid phase, $1.0 \mathrm{~g} / \mathrm{cm}^{3}$ ). Elemental composition was determined by X-ray fluorescence analysis (EDX-900HS energy dispersive spectrometer).

The $\operatorname{poly}(\beta$-caprolactone) composites can be to be used as bone analogous materials in applications such as bone fracture fixation devices or, in the case of a porous structure, scaffolds for bone tissue engineering [6].

For the education of the implant used the poly( $\beta$-caprolactone):

$$
\left[-\left(\mathrm{CH}_{2}\right)_{5}-\mathrm{COOH}-\right]_{\mathrm{n}} \text {. }
$$

For research receive the following mixture of the poly $(\beta$ caprolactone) with doped calcium carbonate-phosphate: $5 \%, 10 \%$ and $15 \%$. Polycaprolactone previously heated in water to the softening temperature $\left(70-80^{\circ} \mathrm{C}\right)$. Poly $(\beta$-caprolactone $)$ is often used as resorptive material thermal implant prolonged action (filler), has both the ability to stimulate the growth of fibrous tissue. $\operatorname{Poly}(\beta$-caprolactone) is a biodegradable polymer with a low melting point and a glass transition temperature of about $60^{\circ} \mathrm{C}$.

A test on stretch and compression ware performed on a Zwick/ Roell Z2.5 universal testing machine. The samples were used in the form of a parallelepiped with a height of $8.8 \mathrm{~mm}$ and a cross-section of $30.5 \mathrm{~mm}$.

The animals (50Wistar male rats) were assigned to the following five test groups: group I (placebo, distilled water); the animals of II 
$-\mathrm{V}$ group were with the $50 \%$ doped calcium carbonate -phosphate suspension in $1 \mathrm{~mL}$ of the vehicle, once daily, for a period of 40 days. Throughout the dosing, the animals were examined for any clinical signs of morbidity, mortality and changes in food consumption. At the end of the treatment, blood was collected from the heart cavity for clinical pathology assessment, which included analysis of various hematology parameters and biochemical parameters. II group was accepted on the 10th day, III- on the 20th, IV - 30th, V - the 40th day accordingly. A Testmetric M500-100AT universal testing machine (100 $\mathrm{KN}$ maximum load, embedded computer) was used in the experiment.

\section{Results experimental and discussion}

The synthesis of nanocrystalline calcium carbonate-phosphate doped with microelements and having a transdermal effect was performed by the development of ammonium calcium hydroxycarbonate containing different doping cations of microelements which are specific for living tissue and which enter the calcium channels of the crystal structure. The biomaterial based on doped nanocrystalline calcium carbonate-phosphates has a high degree of resorption; it is used to activate osteogenesis in a human organism of any age in order to both restore and strengthen bone tissues, as well as to strengthen tooth tissue.

The formation of complex compounds of $\mathrm{M}_{\mathrm{c}-\mathrm{x}} \mathrm{M}_{\mathrm{x}}(\mathrm{OH})_{2}\left[\left(\mathrm{CO}_{3}\right)\right.$ $\left.{ }_{x-2} \cdot \mathrm{H}_{2} \mathrm{O}\right]$ is typical for transition elements. For example, in the medium of ammonium hydroxide, three polymorphic forms of $\mathrm{CaCO}_{3} \mathrm{can}$ form metastable ammonium hydroxy-carbonate complexes on the following reaction:

$$
\mathrm{CaCO}_{3}+\mathrm{NH}_{4} \mathrm{OH} \rightleftarrows \mathrm{NH}_{4} \mathrm{CaCO}_{3} \mathrm{OH}
$$

According to the law of mass speed reactions (1) characterizes the equation

$$
\frac{d x_{1}}{d t}=k_{1}\left[\mathrm{NH}_{4}\right][\mathrm{OH}]
$$

The formation of three types of crystal structures of calcium carbonate (in the medium of ammonium hydroxide and ammonium chloride) is typical for the reaction (1): calcite, vaterite, and aragonite, which was proven by the data of XRD.

In Figure 1 shows a crystal of calcite, aragonite, and vaterite. Calcium carbonate has the following crystalline system: calcite is rhombohedral, space group R-3c; hexagonal structure with space group $\mathrm{R} 63 / \mathrm{mmc}$ vaterite; aragonite is orthorhombic with space group Pmcn.

Under the action of ortho-phosphoric acid in the presence of magnesium cations and silicon dioxide, carbonate is replaced in the phosphate group with the formation of $\mathrm{CaHPO}_{4}$ (brushite) according to the reaction

$$
\mathrm{NH}_{4} \mathrm{CaCO}_{3} \mathrm{OH}+\mathrm{H}_{3} \mathrm{PO}_{4}=\mathrm{CaHPO}_{4}+\mathrm{NH}_{3}+\mathrm{CO}_{2}+2 \mathrm{H}_{2} \mathrm{O}
$$

The doping of cations $\mathrm{Mg}^{2+}, \mathrm{Fe}^{2+}, \mathrm{Zn}^{2+}, \mathrm{Mn}^{2+}$ leads to the basic crystal phase of phosphate hydrogen $\mathrm{Ca}_{8} \mathrm{H}_{2}\left(\mathrm{PO}_{4}\right)_{6} \cdot 5 \mathrm{H}_{2} \mathrm{O}$, for example, by equation (3):

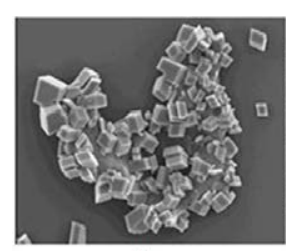

a)

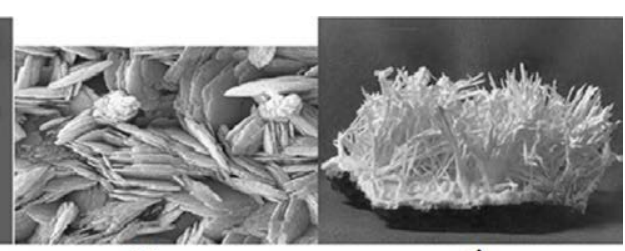

b)

c)
Figure 1. Type of crystals of various calcium carbonates: a) calcite; b) vaterite; c) aragonite.
$10 \mathrm{NH}_{4} \mathrm{CaCO} 3 \mathrm{OH}+6 \mathrm{H}_{3} \mathrm{PO}_{4}=\mathrm{Ca}_{8} \mathrm{H}_{2}\left(\mathrm{PO}_{4}\right)_{6}+2 \mathrm{CaCO}_{3}+8 \mathrm{CO}_{2}+$ $10 \mathrm{NH}_{4} \mathrm{OH}+8 \mathrm{H}_{2} \mathrm{O}$

The reaction rate $(2,3)$ is a direct response

$\frac{d x_{2,3}}{d t}=k_{2,3}\left[\mathrm{NH}_{4}^{+}\right]^{n}\left[\mathrm{OH}^{-}\right]^{n}\left[\mathrm{H}_{2} \mathrm{PO}_{4}^{-}\right]^{m}$

The next stage in the presence of such doping microelements as $\mathrm{K}^{+}, \mathrm{Mg}^{2+}, \mathrm{Fe}^{2+}, \mathrm{Zn}^{2+}, \mathrm{Mn}^{2+}$ and $\mathrm{Si}^{4+}, \mathrm{Au}^{3+}$ is the formation of hydroxychlorapatites according to the following:

$3 \mathrm{CaHPO}_{4}+2 \quad \mathrm{CaCO}_{3}+2 \quad \mathrm{NH}_{4} \mathrm{Cl}+2 \mathrm{NH}_{3}+3 \quad \mathrm{H}_{2} \mathrm{O}+\mathrm{CO}_{2} \rightleftarrows$ $\mathrm{Ca}_{5}\left(\mathrm{PO}_{4}\right)_{2}(\mathrm{OH})_{2} \mathrm{Cl}_{2}+3 \mathrm{NH}_{4} \mathrm{HCO}_{3}+\mathrm{NH}_{4} \mathrm{H}_{2} \mathrm{PO}_{4}$

$\mathrm{Ca}_{8} \mathrm{H}_{2}\left(\mathrm{PO}_{4}\right)_{6}+2 \mathrm{CaCO}_{3}+\mathrm{NH}_{4} \mathrm{Cl}+\mathrm{NH}_{3} \rightleftarrows \mathrm{Ca}_{10}\left(\mathrm{PO}_{4}\right)_{6} \mathrm{OHCl}$ $+2 \mathrm{NH}_{4} \mathrm{HCO}_{3}$

The reaction rate $(4,5)$ is characterizing the equation:

$\frac{d x_{4,5}}{d t}=k_{4,5}\left[\mathrm{NH}_{4}^{+}\right]\left[\mathrm{Cl}^{-}\right]$.

In addition $\mathrm{CaHPO}_{4}$ transforms into $\mathrm{CaCO}_{3}$ :

$\mathrm{CaHPO}_{4} \rightleftarrows \mathrm{CaCO}_{3}$

Thereby in the presence of such doping as $\mathrm{K}^{+}, \mathrm{Mg}^{2+}, \mathrm{Fe}^{2+}, \mathrm{Zn}^{2+}, \mathrm{Mn}^{2+}$, $\mathrm{Au}^{3+}, \mathrm{Si}^{4+}$ microelements is the formation of hydroxychlorapatites. The general schema will be the next:

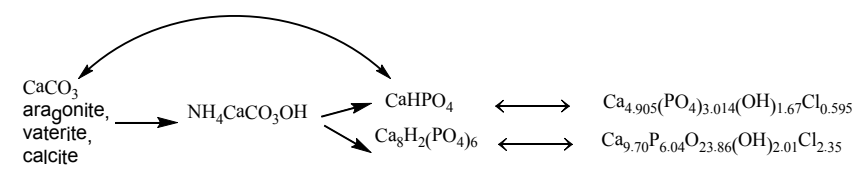

The samples compositions inferred from chemical analysis, X-Ray diffraction (XRD Figure 2, Table 1), and IR spectroscopy data agree well. In Fig. 2 presented diffraction pattern of doped cations magnesium, zinc, iron (a) and doped magnesium, zinc, iron, gold (b) calcium carbonate-phosphate.

In this connection (samples gold calcium carbonate-phosphate include: brushit-36.6\%; calcite-13.5\% \%; hydroxyapatite $\mathrm{Ca}_{5}\left(\mathrm{PO}_{4}\right)_{3} \mathrm{OH}$ $-14.8 \% \%$; struvit $\mathrm{MgNH}_{4} \mathrm{PO}_{4}\left(6 \mathrm{H}_{2} \mathrm{O}-4.5 \%\right)$. SEM micrographs of synthetic calcium carbonate: calcite, vaterite, and aragonite and doped Fe 0.004; Mg 0.007; Zn 0.002; Mn 0.00002 mol. \% calcium carbonatephosphate shown in Figure 3.

The IR spectra of the samples doped calcium carbonate-phosphates show absorption bands due valence vibrations of the group at $\delta_{\mathrm{s}}=525$, 560 , and $600 \mathrm{~cm}^{-1}$; symmetric vibrations at $v_{1}=525,560$ and $600 \mathrm{~cm}^{-1}$ and asymmetric vibrations at $v_{3}=1038,1078,1100-1118 \mathrm{~cm}^{-1}$ and also an absorption band corresponding the deformation vibrations of the group at $v_{3}=1420 \mathrm{~cm}^{-1}$. The absorption band $1630 \mathrm{~cm}^{-1}$ corresponds to deformation vibrations $\mathrm{OH}$-water groups. Absorption band 3800 $\mathrm{cm}^{-1}$ corresponds to valence vibrations molecule $\mathrm{H}_{2} \mathrm{O}$ and are features crystallization water. The values for the triplet valence fluctuation of the phosphate- group $\delta_{B}$ agree to known [37].

The particle-size analysis has shown that the composition of calcium carbonate-phosphate samples is polydisperse. The basic fraction of particles ranges from 5 to 20 microns for samples doped with cations. In addition the ultra-dispersed fraction with the size of particles up to $10 \mathrm{~nm}$ in amounts of $4.5 \%$ is observed.

When conducting biomedical research it was found that owing transit to doped calcium carbonate-phosphate through the epithelium and through the skin is increase of the bone strength in living organism, it restores the trauma bone tissue and tooth tissue $[38,39]$. 


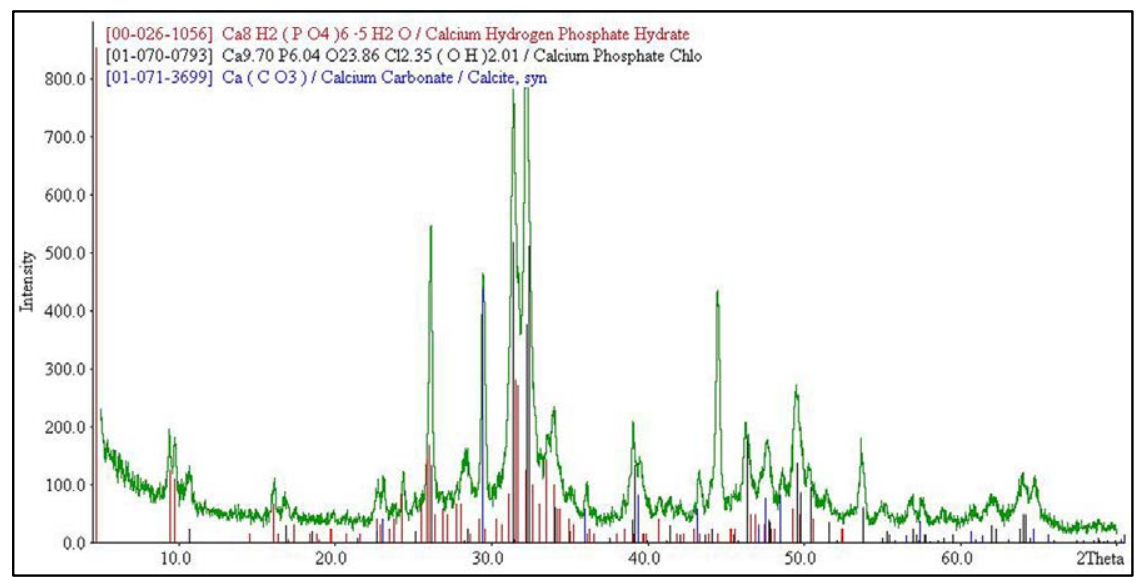

a)

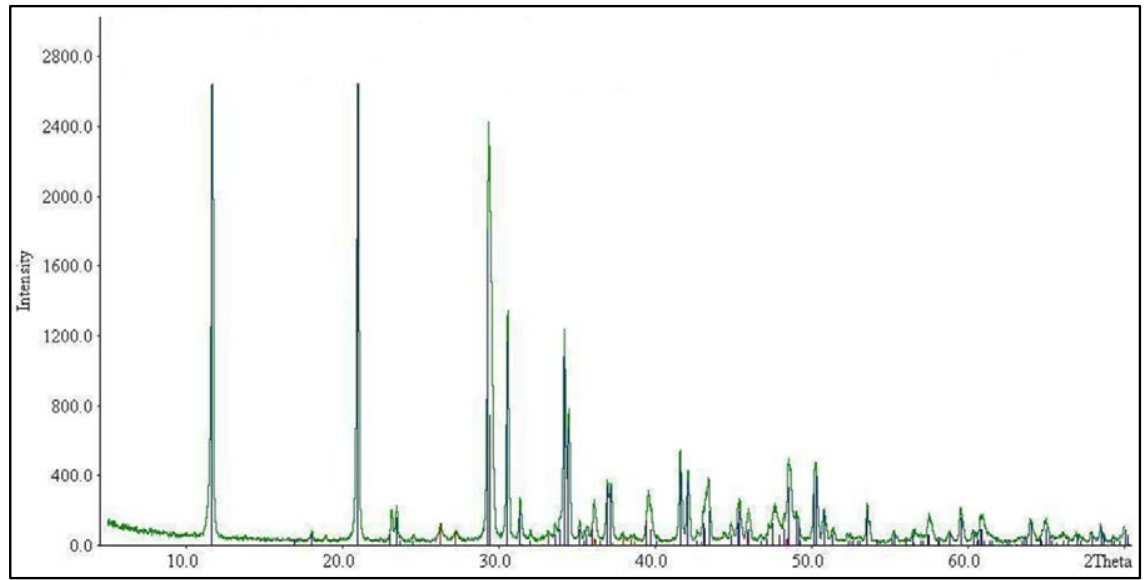

b)

Figure 2. XRD pattern of doped calcium carbonate- phosphates: doped magnesium, zinc, iron (a) and doped magnesium, zinc, iron, gold (b).

Table 1. Elemental and phase compositions of doped calcium carbonate phosphates.

\begin{tabular}{|c|c|c|c|c|c|c|}
\hline \multicolumn{6}{|c|}{ Mole percent } & Phase composition, wt. \% \\
\hline $\mathrm{Fe}$ & $\mathrm{Mg}$ & $\mathrm{Zn}$ & $\mathrm{K}$ & $\mathrm{Mn}, \mathrm{Au}$ & $\mathrm{SiO}_{2}$ & \\
\hline 0,001 & 0,02 & - & - & - & - & $\begin{array}{ll}\mathrm{CaH}_{2}\left(\mathrm{PO}_{4}\right)_{6} * 5 \mathrm{H}_{2} \mathrm{O} & 76 \% \\
\mathrm{Ca}_{9.70} \mathrm{P}_{6.04} \mathrm{O}_{23.86} \mathrm{Cl}_{2.35}(\mathrm{OH})_{2.01} & 18 \%\end{array}$ \\
\hline 0,001 & 0,005 & 0,002 & - & 0,001 & - & $\begin{array}{l}\mathrm{CaH}_{2}\left(\mathrm{PO}_{4}\right)_{6} * 2 \mathrm{H}_{2} \mathrm{O} \\
\mathrm{Ca}_{9.70} \mathrm{P}_{6.04} \mathrm{O}_{23.86} \mathrm{Cl}_{2.35}(\mathrm{OH})_{2.01}\end{array}$ \\
\hline 0,001 & 0,004 & 0,002 & & & & $\begin{array}{l}\mathrm{CaH}_{2}\left(\mathrm{PO}_{4}\right)_{6} * 2 \mathrm{H}_{2} \mathrm{O} \\
\mathrm{Ca}_{9.70} \mathrm{P}_{6.04} \mathrm{O}_{23.86} \mathrm{Cl}_{2.35}(\mathrm{OH})_{2.01}\end{array}$ \\
\hline 0,002 & 0,06 & 0,002 & & & & $\begin{array}{l}\mathrm{CaH}_{2}\left(\mathrm{PO}_{4}\right)_{6} * 2 \mathrm{H}_{2} \mathrm{O} \\
\mathrm{Ca}_{9.70} \mathrm{P}_{6.04} \mathrm{O}_{23.86} \mathrm{Cl}_{2.35}(\mathrm{OH})_{2.01}\end{array}$ \\
\hline 0,002 & 0,01 & 0,002 & & & & $\begin{array}{ll}\mathrm{CaH}_{2}\left(\mathrm{PO}_{4}\right)_{6}{ }^{* 2 \mathrm{H}_{2} \mathrm{O}} & 70 \% \\
\mathrm{Ca}_{9.70} \mathrm{P}_{6.04} \mathrm{O}_{23.86} \mathrm{Cl}_{2.35}(\mathrm{OH})_{2.01} & 18 \%\end{array}$ \\
\hline 0,003 & 0,02 & - & 0,001 & - & - & $\mathrm{CaH}_{2}\left(\mathrm{PO}_{4}\right)_{6} * 2 \mathrm{H}_{2} \mathrm{O}$ \\
\hline- & 0,06 & - & 0,001 & - & - & $\begin{array}{lc}\mathrm{CaH}_{2}\left(\mathrm{PO}_{4}\right)_{6} * 2 \mathrm{H}_{2} \mathrm{O} & 85 \% \\
\mathrm{Ca}_{9.70} \mathrm{P}_{6.04} \mathrm{O}_{23.86} \mathrm{Cl}_{2.35}(\mathrm{OH})_{2.01} & 7 \% \\
\mathrm{Ca}^{2} \mathrm{H}_{2}\left(\mathrm{PO}_{4}\right)_{6} * \mathrm{H}_{2} \mathrm{O}-\mathrm{KHCO}_{3}-\mathrm{H}_{2} \mathrm{O} \%\end{array}$ \\
\hline- & 0,003 & - & - & - & 0,002 & $\begin{array}{l}\mathrm{CaHPO}+2 \mathrm{H}_{2} \mathrm{O} \\
\mathrm{Ca} 8 \mathrm{H}_{2}\left(\mathrm{PO}_{4}\right)_{6} * 5 \mathrm{H}_{2} \mathrm{O}\end{array}$ \\
\hline- & 0,01 & - & 0,001 & - & - & $\mathrm{CaHPO}_{4} * 2 \mathrm{H}_{2} \mathrm{O}$ \\
\hline 0,0004 & 0,035 & 0,002 & - & - & - & $\mathrm{CaH}_{2}\left(\mathrm{PO}_{4}\right)_{6} * 5 \mathrm{H}_{2} \mathrm{O}$ \\
\hline- & 0,02 & - & - & - & - & $\begin{array}{l}\mathrm{CaHPO}_{4} * 2 \mathrm{H}_{2} \mathrm{O} 10 \% \\
\mathrm{CaH}_{2}\left(\mathrm{PO}_{4}\right)_{6} * 5 \mathrm{H}_{2} \mathrm{O}\end{array}$ \\
\hline
\end{tabular}


Evidence is the participation in the osteogenesis doped calcium carbonate-phosphate in the process of rebuilding bone with bone fractures and its reinforcement. In addition, when realize the subcutaneous implantation the powder form after 26-30 days doped calcium carbonate-phosphate fully absorbed in tissues of animals without any inflammatory reactions. There has been an increase in the concentration of calcium and mechanical fracture strength of the bone tissue [39].

It was established that the level of cholesterol in the blood plasma, including low- density lipoprotein decreases 2-2,5 times, which is particularly positive (Figure 4).

The level of cholesterol significantly decreases that may be a positive sign of doped calcium carbonate-phosphate influence [40].

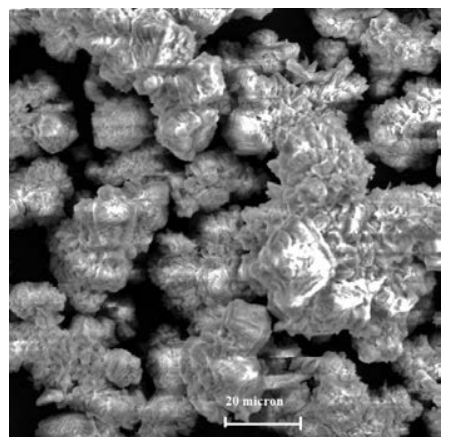

a)

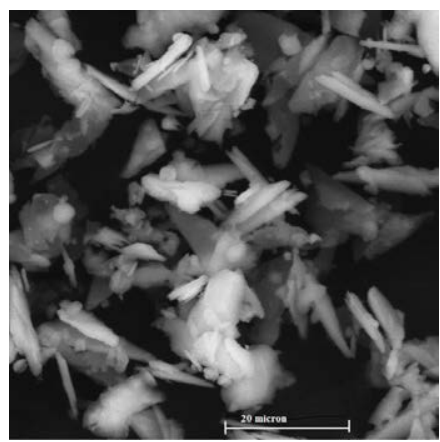

b)
Figure 3. Scanning electron micrographs of calcium carbonate (a): calcite, vaterite, and aragonite; of doped Fe 0.004; Mg 0.007; Zn 0.002; Mn 0.00002 mol. \%, Au 0.001 mol. \% calcium carbonate-phosphate (b).

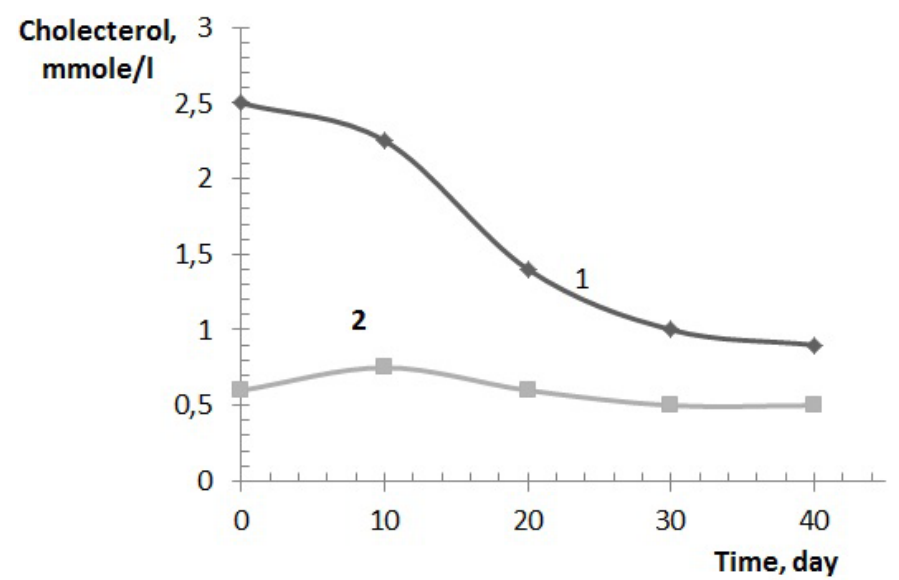

Figure 4. Change cholesterol general (1), high density lipoproteins (2) in the blood plasma of animals

Histological data suggest the positive role of the studied compositions based on doped calcium carbonate-phosphate on bone regeneration process fracture.
The influence of doped calcium carbonate-phosphate on the structure of newly formed bone tissue in the area of the fracture has research using histomorphological analysis. The samples of bone calluses in animals investigated receiving treatment in the form of doped calcium carbonate-phosphate.

Sampling carried out on 60 day after surgical intervention after humane euthanasia. At 60 days of histologically observed the existence of hotbeds of cartilage tissue samples of bone calluses animals (Figure $5 a)$, whereas prototypes receiving treatment with doped calcium carbonate-phosphate is defined fully formed bone (Figure $5 b$ ).

Figure 6 presents a diagram of tensile strength for the destruction of bone tissue depending on the samples of doped calcium carbonatephosphates used for introduction into the animals.

The mechanical fracture strength of bone tissue increases almost 5 times.

For the education of the implant used the poly( $\beta$-caprolactone). For research was generating of the following mixture of the

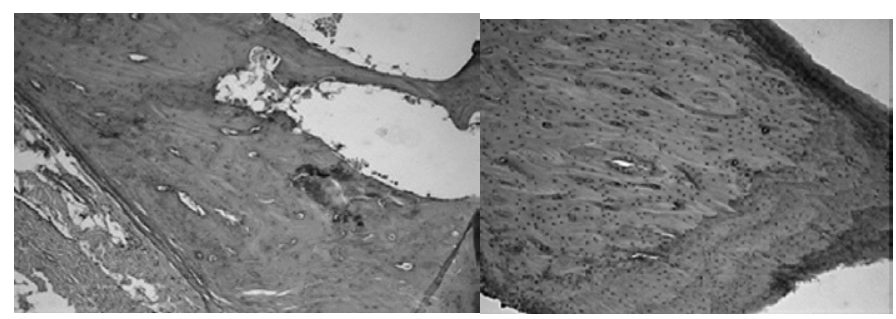

a)

b)

Figure 5. Bone tissue later fracture: a) fracture without treatment; b) treatment with doped calcium carbonate-phosphate.

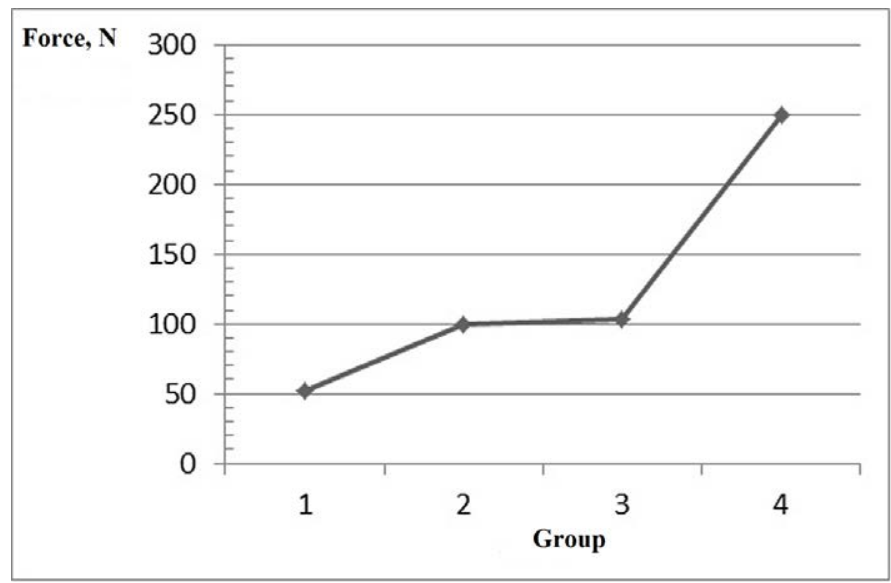

Figure 6. Mechanical fracture strength of bone tissue depending on the samples of doped calcium carbonate-phosphates used for the introduction into animals: point 1 on the $\mathrm{x}$-axis is placebo, point 2 - sample 1, point 3 - sample 2, point 4 - sample 3 (Table 2).

Table 2. The samples of doped calcium carbonate-phosphate.

\begin{tabular}{|c|c|c|c|c|c|}
\hline \multicolumn{6}{|c|}{ Chemical elements, sample 1} \\
\hline Ca, wt.\% & P, wt.\% & $\mathrm{Mg}, \mathrm{mol} . \%$ & $\mathrm{Fe}, \mathrm{mol} . \%$ & $\mathrm{~K}, \mathrm{~mol} . \%$ & $\mathrm{Li}, \mathrm{mol} . \%$ \\
\hline $33-35$ & $16-17$ & 0.005 & 0.001 & $0.002-0.003$ & 0.003 \\
\hline \multicolumn{6}{|c|}{ Chemical elements, sample 2} \\
\hline Ca, wt.\% & P, wt.\% & $\mathrm{Mg}, \mathrm{mol} . \%$ & $\mathrm{Fe}, \mathrm{mol} . \%$ & $\mathrm{~K}, \mathrm{~mol} . \%$ & $\mathrm{Zn}, \mathrm{mol} . \%$ \\
\hline $33-35$ & $16-17$ & 0.005 & 0.002 & $0.002-0.03$ & 0.02 \\
\hline \multicolumn{5}{|c|}{ Chemical elements, sample 3} & \\
\hline $\mathrm{Ca}$, wt.\% & P, wt.\% & $\mathrm{Mg}$ & $\mathrm{Fe}$ & $\mathrm{SiO}_{2}$ & \\
\hline $33-35$ & $16-17$ & 0.004 & 0.001 & 0.002 & \\
\hline
\end{tabular}


polycaprolactone with doped calcium carbonate-phosphate: $5 \%, 10 \%$ and $15 \%$.

Figure 7 presents a diagram of tensile strength for the destruction of the samples implants depending on the content of doped calcium carbonate-phosphate used for introduction into the $\operatorname{poly}(\beta$ caprolactone).

In Table 3 shows of uniaxial tensile test results, carry out when testing polycaprolactone composite with doped calcium carbonatephosphate. The experimental results have been processed by methods of mathematical statistics. The best results have been observed with concentrations of 5-10\% doped calcium carbonate-phosphate. Young 's modulus is maximal for specimens with $5 \%$ doped calcium carbonatephosphate.

Thus, the possibility of application of doped calcium carbonatephosphate has for implants by bone defects. These studies suggest doped calcium carbonate-phosphate is the most appropriate material, because reduce of the cholesterol rate in the blood.

\section{Conclusion}

The synthesis of nanocrystalline doped calcium carbonate phosphate with a transdermal effect was fulfilled by the creation through ammonium calcium hydroxy-carbonate complexes with entering doping cations of microelements which are specific for living tissue. Doped nanocrystalline calcium carbonate-phosphate extends significantly the functionality for drug delivery: it can be used to acceleration up the processes of bone repair and bone tissue strengthening. The advantage over other calcium phosphate biomaterials is strengthening of bone and tooth tissues of a human

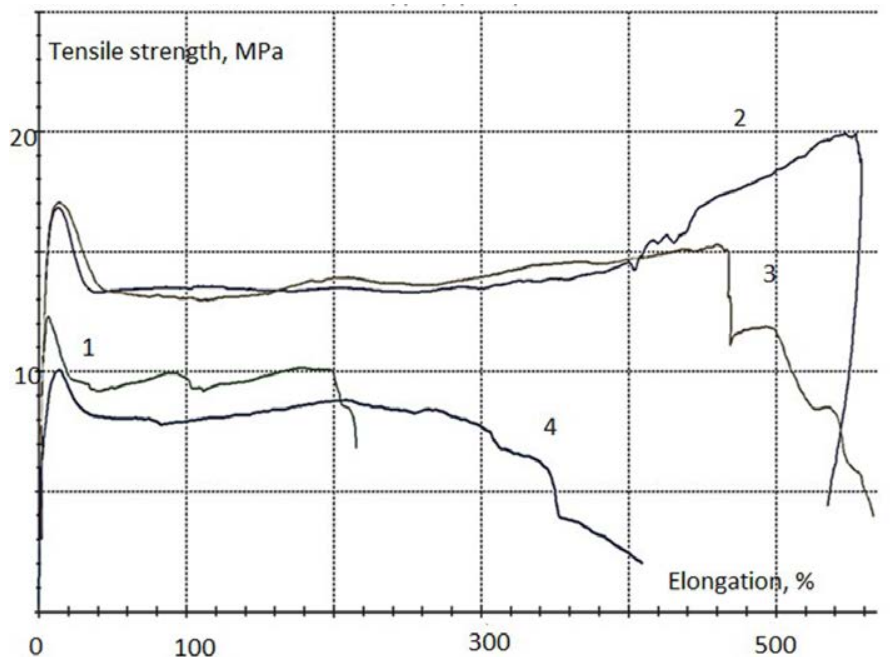

Figure 7. Characteristic diagram of tensile strength of the implants samples depending on the content of doped calcium carbonate-phosphate: 1 curve $-0 \% ; 2$ curve $-5 \% ; 3$ curve $10 \% ; 4$ curve $-15 \%$.

Table 3. Test of uniaxial tensile results.

\begin{tabular}{|c|c|c|c|c|}
\hline № & $\begin{array}{c}\boldsymbol{\delta}, \\
\text { Elongation } \\
\text { \% }\end{array}$ & $\begin{array}{c}\text { E, } \\
\text { Young s modulus, } \\
\mathbf{G P a}\end{array}$ & $\begin{array}{c}\boldsymbol{\sigma}_{\mathbf{s}}, \\
\text { Strength, } \\
\text { MPa }\end{array}$ & Comment \\
\hline $1(0 \%)$ & 215 & 0,331 & 12,3 & homogeneous \\
\hline $2(5 \%)$ & 535 & 0,426 & 19,9 & homogeneous \\
\hline $3(10 \%)$ & 566 & 0,392 & 17,0 & homogeneous \\
\hline $4(15 \%)$ & 409 & 0,286 & 10,1 & $\begin{array}{c}\text { The structure of } \\
\text { the sample is not } \\
\text { homogeneous }\end{array}$ \\
\hline
\end{tabular}

being of any age, the substances being transported through skin to restore broken bones in a critically short period of time regardless of age. The mechanical fracture strength of bone tissue increases almost in 5 times. The level of cholesterol significantly decreases; this is a positive role of doped calcium carbonate-phosphate. The possibility of application of doped calcium carbonate-phosphate has for implants by bone defects.

The biomaterial based on nanocrystalline calcium carbonatephosphates doped with $\mathrm{K}^{+}, \mathrm{Mg}^{2+}, \mathrm{Fe}^{2+}, \mathrm{Zn}^{2+}, \mathrm{Mn}^{2+}, \mathrm{Au}^{3+}, \mathrm{SiO}_{2}$ can be considered a new-generation medicinal substance by drug delivery.

\section{Acknowledgement}

The equipment installed in the Center of Collective Use (CCU) of the Institute of Engineering Science, Russian Academy of Sciences (Ural Branch), was used in the experiment. The research was supported by the Russian Foundation for Basic Research - Urals, project No 0703-96076-[a].

\section{References}

1. Bouyer E, Gitzhofer F, Boulos MI (2000) Morphological study of hydroxyapatite nanocrystal suspension. J Mater Sci: Mater Med 11: 523-531.

2. Champion E (2013) Sintering of calcium phosphate bioceramics. Acta Biomater 9: 5855-5875. [Crossref]

3. Kalita SJ, Bhardwaj A, Bhatt HA (2007) Nanocrystalline calcium phosphate ceramics in biomedical engineering. Mater Sci and EngC 27: 441-449.

4. Hong L, Zhu MY, Li LH, Zhou (2008) Processing of nanocrystalline hydroxyapatite particles via reverse microemulsions. J Mater Sci 43: 384-389.

5. Sunl RX, Lu YP (2008) Fabrication and characterization of porous hydroxyapatite microspheres by spray-drying method. Frontiers of Materials Science in China 2: 95-98.

6. Mohammadi MS, Ahmed I, Muja N, Almeida S, Rudd CD, et al. (2012) Effect of Si and $\mathrm{Fe}$ doping on calcium phosphate glass fibre reinforced polycaprolactone bone analogous composites. Acta Biomater 8: 1616-1626.

7. Fomin AS, Barinov SM, Ievlev VM, Smirnov VV, Mikhailov BP, et al. (2008) Nanocrystalline Hydroxyapatite Ceramics Produced by Low-Temperature Sintering after High-Pressure Treatment. Doklady Chemistry 418: 22-25.

8. Wopenka TB, Pasteris JD (2005) A mineralogical perspective on the apatite in bone Materials Science and Engineering: C 25: 131-143.

9. Brandt A, Henning S, Michler G, Hein W, Bernstein A, et al. (2010) Nanocrystalline hydroxyapatite for bone repair: an animal study. J Mater Sci: Mater Med 21: 283-294.

10. Yu D (2004) Tretyakov. Development of inorganic chemistry as a fundamental for the design of new generations of functional materials. Russian Chemical Reviews 73: 831-846.

11. Shepherd JH, Shepherd DV, Best SM (2012) Substituted hydroxyapatites for bone repair. J Mater Sci: Mater Med 23: 2335-2347.

12. Xia W, Lindahl C, Persson C, Thomsen P, Lausmaa J, et al. (2010) Changes of Surface Composition and Morphology after Incorporation of Ions into Biomimetic Apatite Coatings. J of Biomaterials and Nanobiotechnology 1: 7-16.

13. Dorozhkin SV (2011) Biocomposites and hybrid biomaterials based on calcium orthophosphates. Biomatter 1: 3-56. [Crossref]

14. Bohner M (2010) Resorbable biomaterials as bone graft substitutes. Materialstoday 13: $24-30$.

15. Driessens FCM, Wolke JGC, Jansen JA (2012) A new theoretical approach to calcium phosphates, aqueous solutions and bone remodeling. Journal of the Australian Ceramic Society 48: 144-149.

16. Noor Z (2013) Nanohydroxyapatite Application to Osteoporosis Management. Journal of Osteoporosis 2013: 679025.

17. Parthiban SP, Kim Y, Kikuta K, Ohtsuki C (2011) Effect of ammonium carbonate on formation of calcium-deficient hydroxyapatite through double-step hydrothermal processing. J Mater Sci: Mater Med 22: 209-216.

18. Ezhova ZA, Koval EM, Zakharov NA, Kalinnikov VT (2011) Synthesis and physicochemical characterization of nanocrystalline chitosan-containing calcium 
carbonate apatites. Russian Journal of Inorganic Chemistry 56: 841-846

19. Koroleva LF (2010) Doped Nanocrystalline Calcium Carbonate Phosphates. Inorganic Mater 46: 405-411

20. Koroleva LF, Larionov LP, Gorbunova NP (2012) Doped calcium carbonate-phosphate - based biomaterial for active osteogenesis. Chapter 5. In Book Osteogenesis. InTech, Croatia.

21. Koroleva LF, Larionov LP, Gorbunova N (2012) Biomaterial based on doped calcium carbonate-phosphate for Active Osteogenesis. J of Biomaterials and Nanobiotechnology 3: 226-237.

22. Koroleva LF, Cherednichenko NV, Dobrinskay MN (2014) Doped Nanocrystalline Calcium Carbonate-Phosphate - Biomaterial with Transdermal Activity for Osteogenesis. Chapter 14. In Book: Nanotechnology. Biomaterials. Vol. 11. Edited by Naveen Kumar Navani and Shishir Sinha, STUDIUM PRESS LLC, USA-India.

23. Tas AC, Aldinger F (2005) Formation of apatitic calcium phosphates in a Na-Kphosphate solution of pH 7.4. J Mater Sci Mater Med 16: 167-174. [Crossref]

24. Shepherd JH, Shepherd DV, Best SM (2012) Substituted hydroxyapatites for bone repair. J Mater Sci: Mater Med 10: 2335-2347. [Crossref]

25. Manjubala I, Sampathkumar TS (2001) Preparation of biphasic calcium phosphate doped with magnesium fluoride for osteoporotic applications. J of Mater Sci Let 20 $1225-1227$.

26. Julien M, Khairoun I, LeGeros RZ, Delplace S, Pilet P, et al. (2007) Physico-chemicalmechanical and in vitro biological properties of calcium phosphate cements with doped amorphous calcium phosphates. Biomaterials 28: 956-965.

27. Taukumova LA, Mouravjoy YuV, Gribakin SG (1999) Mucocutaneous side effects and continuation of aurotherapy in patients with rheumatoid arthritis. Adv Exp Med Biol 455: $367-373$

28. Sia O (1991) A method of continuous aurotherapy for rheumatoid arthritis patients under the control of gold excretion. Sov Med 7: 82-83.
29. Shaw III CF1 (1999) Gold-based therapeutic agents. Chem Rev 99: 2589-2600. [Crossref]

30. Koroleva LF (2010) An oscillating mechanism in the synthesis of doped nanocrystalline calcium carbonate phosphates. Nanotechnologies in Russia 5: 635-640.

31. Prigozhine IR, Lefever R (1968) Symmetry breaking instabilities indissipative Systems J Chem Phys 48: 1665-1700.

32. Hermann Wimmel (1992) Quantum physics \& observed reality: a critical interpretation of quantum mechanics. World Scientific.

33. Schrödinger E (1926) An Undulatory Theory of the Mechanics of Atoms and Molecules Phys Rev 28: 1049-1070.

34. Eremin VV, Pakhomova Y, Kuz'menko NE (2004) Kinetic modeling of femtosecond dinamics of nuclei in systhems with avoided crossing of electronic terms. Russian Journal of Physical Chemistry A 78: 735-740.

35. Jung E, Choi SH, Lee NK, Kang SK, Choi YJ, et al. (2011) Machine learning study for the prediction of transdermal peptide. J Comput Aided Mol Des 25: 339-347. [Crossref]

36. Higgins JA (1954) A chemical mechanism for oscillations in glicolitic intermediates in yeast cells. Proc Nat Acad Sci USA 51: 989-994. [Crossref]

37. Smirnov VV, Barinov SM, Ievlev VM (2008) Calcium Phosphate Bone Cement Perspekt Mater 1: 26-30.

38. Koroleva LF (2014) Nanocrystalline doped calcium carbonate-phosphates as a biomaterial for osteogenesis. Research Journal of Pharm Biolog and Chem Sci 5: 704-710.

39. Koroleva LF, Dobrinskaya MN, Kamantsev IS (2015) Doped nanocrystalline calcium carbonate-phosphate - a biomaterial for bone repair and strengthening by drug delivery. Diagnostics, Resource and Mechanics of materials and structure 5: 147-152.

40. Dobrinskaya MN, Larionov LP, Koroleva LF (2016) Acute and subchronic toxicity investigation of new doped nanocrystallited materials. IRF International conference (IraJ Research Forum) India, Goa Pp. 32-35.

Copyright: (C2017 Koroleva LF. This is an open-access article distributed under the terms of the Creative Commons Attribution License, which permits unrestricted use, distribution, and reproduction in any medium, provided the original author and source are credited. 